\title{
An Analytical study for the Relationship between Accounting for Securitization and Fair value Accounting and its Impact on Earnings Management for Companies \\ Listed on the Stock Exchange \\ Ahmed Zaky ${ }^{\text {a }}$ Ragia Shelih
}

a. Professor, Faculty of Commerce, Suez Canal University, Egypt.

b. Assistant Professor, Faculty of Commerce, Suez Canal University, Egypt.

\section{Abstract}

The research investigates whether banks are motivated to manage earnings through securitization gains when earnings before securitization are low or when there are more negative changes in earnings before securitization under SFAS 140. The research also examines if earnings management incentives are eliminated after the adoption of SFAS 166. Moreover, the study examines if managers use discretion afforded by fair value accounting rules to manage securitization gains under SFAS 140. A sample of U.S. Bank Holding Companies (BHCs) listed on the New York stock exchange (NYSE) and the NASDAQ are selected which cover two time periods: Pre-SFAS 166 (2007-2009) and Post-SFAS 166 (2010-2016). A Panel Data Analysis is utilized to examine securitization transactions in these two time periods. The results of the study provide evidence of earnings management when securitization transactions are conducted in accordance with SFAS 140 rules. Furthermore, the research finds that bank managers use their discretion over fair value accounting measurements to manage securitization gains in the Pre-SFAS 166 period. However, there is no evidence of earnings management under SFAS 166 rules suggesting that companies have become more conservative after the adoption of SFAS 166. 
An Analytical study for the Relationship between Accounting for Securitization ...

Prof. Ahmed Zaky \& Ass.Prof. Ragia Shelih

Key Words: Securitization, Fair Value Accounting, Earnings

Management, SFAS 140/166.

\section{Introduction}

Securitization is an important feature of modern financial systems (Bertay et al., 2017). The years preceding the financial crisis had been characterized by a boom in worldwide securitization markets. The issuing of securitization products had more than tripled, from less than 700 billion US dollars in the year 2000 to around 2800 billion in the year 2006 (Bertay et al., 2017). Between year 2000 and 2010, the size of the global securitization market increased from 4.8 trillion US dollars to 13.6 trillion (Buchanan, 2016). After a long period of development, the crisis caused an effective breakdown of worldwide securitization markets, resulting in the collapse of those markets (Briggs and Beams, 2012). Securitization is arguably one of the main triggers of the 2007 global financial crisis (Chen et al., 2017). Over 1300 US mortgage companies have declared bankruptcy (Pagano and Volpin, 2012; Buchanan, 2016).

In the aftermath of the crisis, asset securitizations were criticized by several market participants claiming the opaqueness associated with such activities (Lejard, 2016) and a lot of questions have been raised about the problems inherent in the securitization process (Sarkisyan and Casu, 2013). Accounting regulators have proposed a lot of guidelines pointing to address the deficiencies of the securitization accounting (Sarkisyan and Casu, 2013). Bryan et al. (2010) and Senarath (2016) argue that the weaknesses in the accounting rule SFAS 140 applied to securitization played a major role in the recent economic boom. This resulted in issuing SFAS

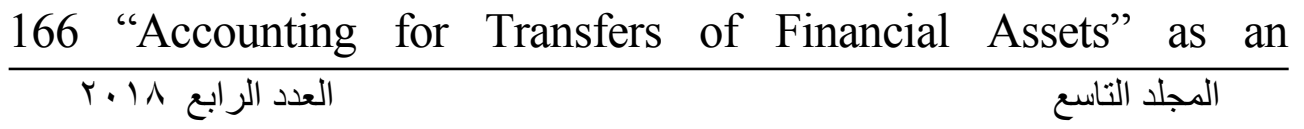


An Analytical study for the Relationship between Accounting for Securitization ...

Prof. Ahmed Zaky \& Ass.Prof. Ragia Shelih

amendment of SFAS 140 "Accounting for Transfers and Servicing of Financial Assets and Extinguishments of Liabilities" to further regulate the recognition of securitization gain in securitization transactions (FASB, 2009).

Concerns about securitization-based earnings' management are raised by several previous studies documenting that the accounting standards related to securitization can be misused by managers to smooth earnings (Karaoglu 2005; Feng et al., 2009; Dechow et al. 2010). Moreover, the recent financial crisis has led to a major debate about fair value accounting hierarchy among accounting and banking regulators, researchers and many others (Sodan, 2015). Bryan and Lilien (2013) indicated that fair value measurement for securitization has been problematic and gained a lot of attention particularly in relation to SFAS 140. Several commentators argue that fair value accounting has not lived up to its expectations of increasing transparency in financial reporting (Krumwiede, 2008) particularly in relation to Level 3 valuations (Cheng, 2012; Huizinga and Laeven, 2009; Dechow et al., 2010). The flexibility offered in fair value estimates create opportunities for management to manipulate earnings (i.e.; Dechow et al., 2010; Cheng, 2012; Fargher and Zhang, 2014). The likelihood of manager manipulations to attain their own goals has been subject to various research conducted for understanding whether managers have incentives as well as a possibility for earnings management practices under fair value accounting (Tutino and Pompili, 2018).

Hence, earnings management examination in the banking sector is very essential because of the substantial influence of these problems on the economy (Dantas et al., 2012). All these concerns have increased during and after the financial crisis era which was accompanied by a strong decline in bank profitability (BIS, 2009;

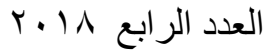

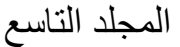


An Analytical study for the Relationship between Accounting for Securitization ...

Prof. Ahmed Zaky \& Ass.Prof. Ragia Shelih

Haan and Oordt, 2017). For these reasons, many questions have been raised about the ability of securitization to work in an appropriate balanced market environment (Riddiough, 2011 and Liang, 2015). As a result, these rationalizes the examination of a possible association between earnings management practices and the discretional use of unobservable inputs in fair value accounting application in securitization settings.

Therefore, a question yet to be addressed is the relative impact of asset securitizations, and whether managers take advantage of the easier criteria of SFAS 140 compared to the currently adopted standard SFAS 166 for securitization and use their discretion over fair value accounting rules to manage earnings. Considering the changes in accounting standards, the research subquestion is "would accounting under SFAS 166 change managers' opportunistic behaviors?"

To address the gap in the literature, this paper examines the following effects: First, it investigates whether managers had incentives to manage earnings through securitization gains to avoid earning decline when earnings before securitization were low during the SFAS 140 period (2007-2009) and whether this incentive was eliminated after the application of SFAS 166.

Second, the research examines if mangers had incentives to manage earnings through securitization gain when there had been more negative changes in a prior year's earnings before securitization under SFAS 140 and if this incentive was eliminated after the adoption of SFAS 166. Third, it determines whether banks use their discretion afforded by fair value accounting rules particularly Level 3 valuations to manage earnings. These three objectives are examined separately under both SFAS 140 and SFAS 166.

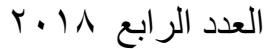

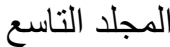




\section{Hypotheses Development}

\subsection{Securitization Gain and Earnings Management Incentives}

Empirical research examining earnings management in securitization settings implies that the motivations for financial reporting discretion depend on the amount of earnings before the effect of the discretion and have interpreted the association between securitization and pre-managed earnings as a measure of earnings management (Kraoglu,2005; Dechow et al., 2010; Ibrahim, 2010; Chen and Tseng, 2012). Therefore, firms exercise discretion over securitization gain to increase earnings when pre-managed current earnings are low or when there is a negative change in pre-managed earnings compared to prior year. SFAS 140 provides banks with the opportunity to manage securitization gains when there is low income before securitization or negative change in earnings before securitization (Chen and Tseng, 2012). Furthermore, securitizations provide a potentially powerful setting for examining earnings management because the amounts of gains and losses recognized from securitization transactions require the exercise of judgment and discretion which facilitates target-based earnings management (Barth and Taylor, 2010; Feng et al., 2009).

Following prior research (e.g., Karaoglu, 2005; Dechow et al., 2010; Chen and Tseng, 2012; Ibrahim, 2010) this study investigates the following two settings in which earnings management incentives are expected to be relatively strong: (1) when earnings before securitization gain are low, managers face more incentive to record securitization gains to avoid earnings decline. (2) when earnings before securitization gain is below last year's earnings, managers are likely to face greater enquiry by investors and regulators, are less likely to receive bonuses, and will face difficulty in attracting employees and customers. 
An Analytical study for the Relationship between Accounting for Securitization ...

Prof. Ahmed Zaky \& Ass.Prof. Ragia Shelih

As a result, this research hypothesizes that there is a significant negative association between securitization gain and both earnings before securitization and the change in earnings before securitization under SFAS 140. However, after the adoption of SFAS 166 which is represented by (2010-2016) period; it is not expected to find any significant association between neither earnings before securitization nor the change in earnings before securitization and the likelihood of reporting securitization gain.

Therefore, the following Hypotheses can be developed:

Hla: In the Pre-SFAS 166, banks are inclined to report higher securitization gains when earnings before securitization are low H1b: In Post-SFAS 166, banks are not inclined to report higher securitization gains when earnings before securitization are low. H2a: In Pre-SFAS 166, banks are inclined to report higher securitization gains when change in earnings before securitization are low.

H2b: In Post-SFAS 166, banks are not inclined to report higher securitization gains when change in earnings before securitization are negative or low.

\subsection{The Impact of Fair Value Accounting Rules on Earnings Management Incentives Through Securitization Gain}

Prior studies revealed that the incentives to meet earnings targets lead managers to make accounting choices that can assist them in meeting or beating those targets (Altamuro and Zhang, 2013; Bratten et al., 2017; Tutino and Pomili, 2018). For earnings management incentives, larger managerial discretion in determining fair value increases managers opportunities to manipulate earnings, which in turn weaken earnings informativeness (Fargher and Zhang, 2014). Hence, managers can use the discretion allowed in 
An Analytical study for the Relationship between Accounting for Securitization ...

Prof. Ahmed Zaky \& Ass.Prof. Ragia Shelih

fair value accounting measurements opportunistically through reporting higher securitization gains.

Banks use securitization gain to increase earnings through aggressively estimating the fair value of the retained components. Thus, earnings management objectives can be achieved through biased valuation of retained interests from securitized assets (Chen and Tseng, 2012). According to Zhang (2014) the amount of securitization gain can be determined by calculating the difference between the fair value and book value of the components sold and components retained. Where the fair value of the components sold is usually equal to selling price, the fair value of the retained components is based on managerial estimations. Since the valuation of retained interests directly and completely determines securitization gain (Ryan et al., 2016), then an increase in the fair value of the retained interests will result in an increase in the value of the gain, and in earnings management practices (Kolsi and Matoussi, 2012). This suggests that both the value of the retained interests and securitization gains are largely discretionary (Kolsi and Matoussi, 2012).

Under SFAS 140, the fair value measurement of the beneficial interests is considered the most difficult and challenging because it is usually measured using Level 3 valuations where no active market exits and is based on managers' assumptions and estimation of internal models (Ryan, 2008; Dechow et al., 2010; Freeman et al., 2017). These assumptions are unlikely to be realistic, the sensitivity of the results to changes prepayment rates, or discount rates may be underestimated (The Office of the Thrift Supervision, 2003). This study suggests that when banks have incentives to report opportunistically (e.g. Low pre-securitization earnings or negative change in pre-securitization earnings), they are

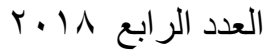

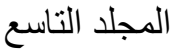


more likely to use the discretion available when measuring Level 3 inputs to enable them to boost their reported income (Yao et al., 2018). However, after the application of SFAS 166 most of the beneficial interests arising from securitization are being measured using Level 2 valuations instead of Level 3 valuations (Freeman et al., 2017).

This research hypothesizes that SFAS 140 accounting for securitization rule encourages banks to use the discretion afforded by level 3 valuations of retained interests to pick a lower discount rate with an aim to obtain higher securitization gains. Accordingly, the third hypothesis can be developed as follows:

H3: Banks use their discretion to choose lower discount rates to obtain higher securitization gains.

\section{Sample Selection and Research Design \\ 3.1 Sample Selection}

A sample of U.S. Bank Holding Companies (BHCs) are selected with reported total assets greater than $\$ 10$ billion which are either listed on New York Exchange (NYE) or NASDAQ stock market. All financial data is collected from the quarterly financial reports of the Consolidated Financial Statements for Bank Holding Companies (BHCs) FR Y- 9C, filed to the Chicago Federal Reserve System and 10-Qs filed with the Securities and Exchange Commission (SEC). The research uses a sample of 20 BHCs. The Pre-SFAS 166 period includes 12 quarters from quarter ending March 2007 up to quarter ending December 2009. The Post-SFAS 166 period includes 28 quarters from quarter ending March 31, 2010 till quarter ending December 31, 2016. This lead to a sample of 240 bank/quarter observations representing SFAS 140 and 560 bank/quarter observations representing the SFAS 166. The research 
An Analytical study for the Relationship between Accounting for Securitization ...

Prof. Ahmed Zaky \& Ass.Prof. Ragia Shelih

will separately examine the 240 banks/ quarters observations in 2007-2009 when SFAS 140 was in effect and then examine 560 bank/quarters observations in 2010- 2016 when SFAS 166 is applied.

To examine the research hypotheses, Panel Data Analysis has been conducted using Econometrics program STATA software for analyzing the data and producing the regression results.

\subsection{Research Design}

Following Dechow et al. (2010) and Ibrahim (2010), this study uses similar models to test the first and the second hypotheses:

GOSiq=B1EBSiq+B2MBSiq+B3CONSBSiq+B4COMMBSiq+eiq... GOSiq=B1 $\triangle$ EBSiq +B2MBSiq +B3CONSBSiq+B4COMMBSiq+eiq...(2)

The dependent variable GOS iq equals the net securitization income for bank $\mathrm{i}$ in quarter q. The independent variable EBS iq equals the net income for bank $\mathrm{i}$ in quarter $\mathrm{q}$ less net securitization income during the same quarter. The independent variable $\triangle E B S$ iq equals EBS in current quarter less EBS in same quarter in prior year. The Control Variables $M B S$ iq equals the outstanding principal balance of 1-4 family residential loans sold and securitized with servicing retained or recourse or other sellerprovided credit enhancements for bank $\mathrm{i}$ in quarter $\mathrm{q}$; the CONSBS iq equals outstanding principal balance of consumer loans sold and securitized with servicing retained or recourse or other sellerprovided credit enhancements for bank $\mathrm{i}$ in quarter q; the COMMBS iq equals outstanding principal balance of commercial loans sold and securitized with servicing retained or recourse or other sellerprovided credit enhancements for bank $i$ in quarter $q$. The variables are deflated by prior quarter total assets to adjust for heteroscedasticity.

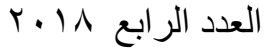


To test the third hypothesis the following model is used:

DR iq = B1GOS iq + B2 EBS iq + B3 INT-GOS-EBS iq +B4MBS iq + B5 CONSBS iq + B6 COMMBS iq + eiq

The dependent variable $D R$ iq equals the discount rate for firm $\mathrm{i}$ in quarter $\mathrm{q}$ used in the estimation of fair values of assets. The independent variables: GOS iq equals the net securitization income for bank $\mathrm{i}$ in quarter q; the $E B S$ iq equals the net income for bank $\mathrm{i}$ in quarter $\mathrm{q}$ less net securitization income during the same quarter; and the INT-GOS-EBS iq equals the interaction variable between GOS and EBS The Control Variables: MBS iq equals the outstanding principal balance of 1-4 family residential loans sold and securitized with servicing retained or recourse or other sellerprovided credit enhancements for bank $\mathrm{i}$ in quarter $\mathrm{q}$; the CONSBS iq equals outstanding principal balance of consumer loans sold and securitized with servicing retained or recourse or other sellerprovided credit enhancements for bank $\mathrm{i}$ in quarter $\mathrm{q}$; and the COMMBS iq equals outstanding principal balance of commercial loans sold and securitized with servicing retained or recourse or other seller-provided credit enhancements for bank $\mathrm{i}$ in quarter $\mathrm{q}$. The variables are deflated by prior quarter total assets to adjust for heteroscedasticity.

\section{Empirical Results}

\subsection{Descriptive Statistics}

Table (1) provides the descriptive statistics for the key variables used in the empirical analysis. The study consists of the 800 banks quarterly observations starting from the beginning March 2007 until the end of December 2016. 
An Analytical study for the Relationship between Accounting for Securitization ...

Prof. Ahmed Zaky \& Ass.Prof. Ragia Shelih

Table (1)

Descriptive statistics Overall $(\mathrm{N}=\mathbf{8 0 0})$

\begin{tabular}{|c|c|c|c|c|c|}
\hline Variables & Mean & SD & Skewnes & Kurtosis & $\begin{array}{c}\text { Jarque- Bera } \\
\text { P-value }\end{array}$ \\
\hline GOS & 0.0081185 & 0.0037273 & -2287 & .4255 & $0.000^{* * *}$ \\
\hline EBS & 0.020767 & 0.47504 & -1.688 & .9952 & $0.000^{* * *}$ \\
\hline$\Delta$ EBS & 0.0140274 & 0.32209 & -.942 & .15201 & $0.000^{* * *}$ \\
\hline MBS & 0.52802 & 1.2300 & .248 & .5664 & $0.000^{* * *}$ \\
\hline COMMBS & 0.99891 & 2.6959 & .211 & .2871 & $0.000^{* * *}$ \\
\hline CONBS & 0.74339 & 2.6421 & .44435 & .22743 & $0.000^{* * *}$ \\
\hline DR & 0.140136 & 0.1345140 & 1.0064 & -731 & $0.000^{* * *}$ \\
\hline $\begin{array}{c}\text { INT-GOS- } \\
\text { EBS }\end{array}$ & 0.62000 & 3.04000 & .067 & .274 & $0.000^{* * *}$ \\
\hline
\end{tabular}

\subsection{Testing Research Hypotheses}

\subsubsection{Testing the First Research Hypothesis}

Table (2) presents the results of testing equation (1) which displays three estimation methods in the panel data analysis for each period: Pre-SFAS 166 and Post-SFAS 166, using the Random Effects method (REM), the Fixed Effects (FEM) and the Ordinary Least Squares (OLS). According to table (2) it can be concluded that all the three models in both periods passed the significance test since the P-values of the F-statistics are less than 0.01 and the panel regression model is effective. 
An Analytical study for the Relationship between Accounting for Securitization ...

Prof. Ahmed Zaky \& Ass.Prof. Ragia Shelih

Table (2)

\section{Results of REM, FEM and OLS Model for Equation (1) GOS iq = B0 +B1 EBS iq+ B2 MBS iq + B3 CONSBS iq + B4 COMMBS iq + eiq}

\begin{tabular}{|c|c|c|c|c|c|c|}
\hline & \multicolumn{2}{|c|}{ Pre- SFAS 166 (2007-2009) } & \multicolumn{2}{c|}{ Post- SFAS 166 (2010-2016) } \\
\hline $\begin{array}{c}\text { Independent } \\
\text { Variables }\end{array}$ & $\begin{array}{c}\text { Random } \\
\text { Effect }\end{array}$ & Fixed Effect & Pooled OLS & $\begin{array}{c}\text { Random } \\
\text { Effect }\end{array}$ & Fixed Effect & Pooled OLS \\
\hline EBS iq & $-.04560 * * *$ & $-.05052^{* * *}$ & $-.041676 * * *$ & -.000181 & -.000161 & -.00039 \\
& $(0.000)$ & $(0.000)$ & $(0.000)$ & $(0.210)$ & $(0.161)$ & $(0.078)$ \\
\hline MBS iq & $.00082^{* * * *}$ & $.00087 * * *$ & $.000759 * * *$ & .00015 & .000141 & .00016 \\
& $(0.000)$ & $(0.000)$ & $(0.000)$ & $(0.083)$ & $(0.063)$ & $(0.052)$ \\
\hline CONSBS iq & $.01421 * * *$ & $.013841 * * *$ & $.014329 * * *$ & .000058 & .000065 & $.000031 *$ \\
& $(0.000)$ & $(0.000)$ & $(0.000)$ & $(0.091)$ & $(0.320)$ & $(0.053)$ \\
\hline COMMBS iq & .00006 & .000062 & .000246 & $.00033 * * *$ & $-000341 * * *$ & $.00035 * * *$ \\
& $(0.785)$ & $(0.841)$ & $(0.276)$ & $(0.000)$ & $(0.000)$ & $(0.000)$ \\
\hline F- Static & $11121.6 * * *$ & $880.38 * * *$ & $4097.69 * * *$ & $1109.13 * * *$ & $171.63 * * *$ & $477.06 * * *$ \\
& $(0.000)$ & $(0.000)$ & $(0.000)$ & $(0.000)$ & $(0.000)$ & $(0.000)$ \\
\hline
\end{tabular}

Note: Significance at the levels of $5 \%, 1 \%$, and $0.1 \%$ are indicated by ${ }^{*}, *$, and ${ }^{* * *}$

\subsubsection{Panel Model Selection}

\section{1-Breusch-Pagan Lagrange Multiplier Test (LM)}

The LM test is conducted to determine whether the OLS or the REM is appropriate for testing the first research hypothesis. 
An Analytical study for the Relationship between Accounting for Securitization ...

Prof. Ahmed Zaky \& Ass.Prof. Ragia Shelih

According to Table (3), the study rejects LM hypothesis in favor of the REM model for both periods.

\section{Table (3)}

The Summary of Breusch and Pagan Lagrange Multiplier Test for Equation (1)

\begin{tabular}{|c|c|c|}
\hline & Pre- SFAS 166 & Post- SFAS 166 \\
\hline Chi-Sq. Statistic & 107.77 & 354.61 \\
\hline Prob>chi2 & 0.000 & 0.000 \\
\hline
\end{tabular}

\section{2- Hausman Test}

The Hausman test is conducted to choose between the REM and FEM. According to Table (4) results show the values for both periods. In the Pre-SFAS 166 period the study rejects the REM in favor of FEM. While, in Post-SFAS 166 period the P-value 0.167 is greater than 0.05; as a result, the study accepts the null hypothesis that the REM is the preferred model.

\section{Table (4)}

The Summary of Hausman test for Equation (1)

\begin{tabular}{|c|c|c|}
\hline & Pre- SFAS 166 & Post- SFAS 166 \\
\hline Chi-Sq. Statistic & 12.40 & 1.90 \\
\hline Prob>chi2 & 0.0004 & 0.1678 \\
\hline
\end{tabular}

The results in Table (1) show the FEM for Pre-FAS 166 period (2007-2009) used for testing H1a and the REM for the postFAS 166 (2010-2016) used for testing H1b. In the Pre-SFAS 166 period, the results revealed that there is a significant negative 
An Analytical study for the Relationship between Accounting for Securitization ...

Prof. Ahmed Zaky \& Ass.Prof. Ragia Shelih

association between GOS and EBS (B1=-.0505293, $\mathrm{p}<0.001)$. The coefficients for the control variables are significantly and positively only two types of asset-backed securities: MBS and CONSBS (B2=.0008721; B3=.0138411, p<0.001) respectively, therefore, at a significance level 1\% H1a is accepted. This empirical evidence significantly supports H1a of the research stating that in Pre-SFAS 166, banks are inclined to report higher securitization gains when earnings before securitization are low which is consistent with the findings of Karaoglu (2005), Dechow et al. (2010), Ibrahim (2010), and Tseng and Chen (2012).

For the Post-SFAS 166 period the results of the random effect column revealed that there is no significant association between GOS and EBS (B1=-.00018175, p>0.05), therefore, at a significance level $1 \% \mathrm{H} 1 \mathrm{~b}$ is accepted. This indicates that banks are not likely to report higher securitization gains when earnings before securitization are low or negative. Moreover, the results suggest that after the application of SFAS 166 in year 2010 banks do not appear to have the tendency to manage securitization gain to meet earnings target. This empirical evidence significantly supports $\mathrm{H} 1 \mathrm{~b}$ of the research stating that in Post-SFAS 166, banks aren't inclined to report higher securitization gains when earnings before securitization are low. Based on the above, it can be concluded that in the pre-SFAS 166 period when earnings before securitization is negative or low banks have incentives to manage earnings through securitization gains. While under post-SFAS 166 period, the findings indicate that securitization gains aren't used as a tool to manage earnings.

\subsubsection{Testing the Second Research Hypothesis}

Table (5) presents the results of testing equation (2) which displays three estimation methods in the panel data analysis for 
An Analytical study for the Relationship between Accounting for Securitization ...

Prof. Ahmed Zaky \& Ass.Prof. Ragia Shelih

each period: Pre-SFAS 166 and Post-SFAS 166, using REM, FEM and OLS. According to table (5), all the three models in both periods passed the significance test since the P-values of the $\mathrm{F}$ statistics are less than 0.01 and the panel regression model is effective.

\section{Table (5)}

\section{Results of REM, FEM and OLS Model Equation (2)}

GOS iq = B1 $\triangle \mathrm{EBS}$ iq + B2 MBS iq + B3 CONSBS iq + B4 COMMBS iq $+\varepsilon$ iq

\begin{tabular}{|c|c|c|c|c|c|c|}
\hline & \multicolumn{3}{|c|}{ Pre-SFAS 166} & \multicolumn{3}{|c|}{ Post- SFAS 166} \\
\hline $\begin{array}{l}\text { Independent } \\
\text { Variables }\end{array}$ & $\begin{array}{l}\text { Random } \\
\text { Effect }\end{array}$ & Fixed Effect & Pooled OLS & Random Effect & Fixed Effect & Pooled OLS \\
\hline$\Delta \mathrm{EBS}$ & $\begin{array}{c}-.02971 * * * \\
(0.000)\end{array}$ & $\begin{array}{c}-.02784 * * * \\
(0.000)\end{array}$ & $\begin{array}{c}-.03081 * * * \\
(0.000)\end{array}$ & $\begin{array}{l}-.00014 \\
(0.355)\end{array}$ & $\begin{array}{c}-.000145 \\
(0.041)\end{array}$ & $\begin{array}{l}-.00022 \\
(0.712)\end{array}$ \\
\hline MBS & $\begin{array}{c}.00075^{* * * *} \\
(0.000)\end{array}$ & $\begin{array}{c}.00086^{* * * *} \\
(0.000)\end{array}$ & $\begin{array}{c}.00066^{* * * *} \\
(0.000)\end{array}$ & $\begin{array}{c}.000144 * * * \\
(0.000)\end{array}$ & $\begin{array}{c}.0001411 * * * \\
(0.000)\end{array}$ & $\begin{array}{c}.000162 * * * \\
(0.000)\end{array}$ \\
\hline CONSBS & $\begin{array}{c}.01338 * * * \\
(0.000)\end{array}$ & $\begin{array}{c}.014381 * * * \\
(0.000)\end{array}$ & $\begin{array}{c}.013650 * * * \\
(0.000)\end{array}$ & $\begin{array}{l}.00006 \\
(0.085)\end{array}$ & $\begin{array}{l}.00006 \\
(0.067)\end{array}$ & $\begin{array}{l}.000038 \\
(0.343)\end{array}$ \\
\hline COMMBS & $\begin{array}{c}-.00123 * * * \\
(0.000)\end{array}$ & $\begin{array}{c}-.00077 * \\
(0.046)\end{array}$ & $\begin{array}{c}-.00224 * * * \\
(0.000)\end{array}$ & $\begin{array}{l}-.00033 \\
(0.182)\end{array}$ & $\begin{array}{l}-.00032 \\
(0.690)\end{array}$ & $\begin{array}{l}-.00037 \\
(0.167)\end{array}$ \\
\hline F-Static & $\begin{array}{c}6585.97 * * * \\
(0.000)\end{array}$ & $\begin{array}{c}576.22 * * * \\
(0.000)\end{array}$ & $\begin{array}{c}2422.58 * * * \\
(0.000)\end{array}$ & $\begin{array}{c}1002.96^{* * * *} \\
(0.000)\end{array}$ & $\begin{array}{l}170.81 \\
(0.000)\end{array}$ & $\begin{array}{c}435.64 * * * \\
(0.000)\end{array}$ \\
\hline
\end{tabular}

Note: Significance at the levels of $10 \%, 5 \%$, and $1 \%$ are indicated by $* * *$, and $* * *$ 


\subsubsection{Panel Model Selection}

\section{1- Breusch-Pagan Lagrange Multiplier Test (LM)}

Based on the results of LM test presented in Table (6), the study rejectes the null hypothesis in favor of the REM model for both periods.

Table (6)

The Summary of Breusch and Pagan Lagrange Multiplier Test Equation (2)

\begin{tabular}{|l|l|l|}
\hline & Pre- SFAS 166 & Post- SFAS 166 \\
\hline Chi-Sq. Statistic & 57.26 & 623.81 \\
\hline Prob>chi2 & 0.000 & 0.000 \\
\hline
\end{tabular}

\section{2- Hausman Test}

According to Table (7), the Hausman test results for Pre-SFAS 166 period rejects the null hypothesis in favor of the FEM. While, under Post-SFAS 166 period the study accepts the null hypothesis that the REM is the preferred model.

\section{Table (7)}

The Summary of Hausman Test Equation (2)

\begin{tabular}{|l|l|l|}
\hline & Pre- SFAS 166 & Post- SFAS 166 \\
\hline Chi-Sq. Statistic & 6.74 & 1.81 \\
\hline Prob>chi2 & 0.0094 & 0.1782 \\
\hline
\end{tabular}

According to the results of table (6) and (7), it can be concluded that the FEM is the appropriate method for testing the second sub-hypothesis H2a for the Pre-SFAS 166 period, while the REM is for is the appropriate model for testing the second subhypothesis H2b in the Post-SFAS 166 period. 
An Analytical study for the Relationship between Accounting for Securitization ...

Prof. Ahmed Zaky \& Ass.Prof. Ragia Shelih

Based on the results shown in Table (5) the FEM is used to test H2a in Pre- SFAS 166 period (2007-2009). The results show the coefficients and p-values including $\Delta$ EBS as the independent variable and GOS as the dependent variable. The findings revealed that there is a significant negative association between GOS and $\Delta$ EBS (B1=-.02784917, P<0.001). The coefficients for the control variables are as expected. Securitization gain is significantly and positively associated with the three types of asset-backed securities: MBS (B2=.00086618, P <0.001), CONSBS (B3=.01438164, P $<0.001$ ), and COMMBS (B4=.00077502, $\mathrm{P}<0.05)$. Therefore, at a significance level $1 \% \mathrm{H} 2 \mathrm{a}$ is accepted. This empirical evidence supports $\mathrm{H} 2 \mathrm{a}$ of the research stating that in Pre-FAS 166 period, banks are inclined to manage securitization gains upwards when the change in the pre- securitization earnings is low or negative. This result is consistent with the findings of Karaoglu (2005), Dechow et al. (2010), Ibrahim (2010), and Tseng and Chen (2012).

In the Post-SFAS 166 period the results of the REM column in table (5) revealed that there is no significant association between GOS and $\Delta$ EBS $(\mathrm{B} 1=-.000149, \mathrm{P}>0.05)$. Thus, it can be concluded that after the adoption of FAS 166 banks incentives to manage earnings through securitization gains has been eliminated. Therefore, at a significance level $5 \% \mathrm{H} 2 \mathrm{~b}$ is accepted. This empirical evidence supports $\mathrm{H} 2 \mathrm{~b}$ of the research stating that in the Post-SFAS 166 period, banks aren't inclined to manage securitization gains when the change in earnings before securitization are low or negative. Overall, it can be concluded that in Pre-SFAS 166 period banks have incentives to manage earnings through securitization gain when $\triangle$ EBS is negative. While in PostFAS 166 period, the findings indicate that securitization gain isn't 
An Analytical study for the Relationship between Accounting for Securitization ...

Prof. Ahmed Zaky \& Ass.Prof. Ragia Shelih

used as a tool to manage earnings, suggesting that there is no any evidence of earnings management.

\subsubsection{Testing the Third Research Hypothesis}

Table (8) presents the results of testing equation (3) which displays three estimation methods in the panel data analysis for each period: Pre-SFAS 166 and Post-SFAS 166, using REM, FEM and OLS. According to table (8), all the three models are significant and effective.

\section{Table (8)}

Results of REM, FEM and OLS Model for Equation (3) DR iq = B1 GOS iq + B2 EBS + B3 INT-GOS-EBS + B4 MBS + B5 CONSBS+ B6 COMMBS + giq

\begin{tabular}{|l|c|c|c|}
\hline \multicolumn{5}{|c|}{ Pre- SFAS 166 (2007-2009) } \\
Independent & Random Effect & Fixed Effect & Pooled OLS \\
\hline GOS iq & $-.00007165^{* *}$ & $-.00007566^{* * *}$ & -.00001267 \\
& $(0.001)$ & $(0.001)$ & $(0.692)$ \\
\hline EBS iq & $-.0000109^{* * *}$ & $-.00001146^{* * *}$ & $-5.617 \mathrm{e}-06^{* * *}$ \\
& $(0.000)$ & $(0.000)$ & $(0.000)$ \\
\hline Int-GOS-EBS & $-8.430 \mathrm{e}-13^{*}$ & $-9.113 \mathrm{e}-13^{* *}$ & $-8.358 \mathrm{e}-13$ \\
& $(0.015)$ & $(0.010)$ & $(0.065)$ \\
\hline MBS iq & $-6.641 \mathrm{e}-08^{*}$ & $-6.508 \mathrm{e}-08^{*}$ & $-5.106 \mathrm{e}-08$ \\
& $(0.020)$ & $(0.024)$ & $(0.142)$ \\
\hline CONSBS iq & $-1.071 \mathrm{e} 06^{* *}$ & $-9.446 \mathrm{e}-07 * *$ & $-3.061 \mathrm{e}-07$ \\
& $(0.002)$ & $(0.007)$ & $(0.512)$ \\
\hline COMMBS iq & $-8.054 \mathrm{e}-08$ & $-1.194 \mathrm{e}-07$ & $-3.861 \mathrm{e}-07 * * *$ \\
& $(0.394)$ & $(0.249)$ & $(0.000)$ \\
\hline F- Static & 435.64 & 41.75 & 12.32 \\
& $(0.000)$ & $(0.000)$ & $(0.000)$ \\
\hline
\end{tabular}


An Analytical study for the Relationship between Accounting for Securitization ...

Prof. Ahmed Zaky \& Ass.Prof. Ragia Shelih

Note: Significance at the levels of $10 \%, 5 \%$, and $1 \%$ are indicated by ${ }^{*}, *$, and ${ }^{* * *}$

\subsubsection{Panel Model Selection}

\section{1- Breusch-Pagan Lagrange Multiplier Test (LM)}

As shown in table (9) the values are significant (Chi-Sq. $=469.23 ; \mathrm{P}$ $<0.01$ ). Therefore, the study rejected the null hypothesis in favor of the REM model.

Table (9)

The Summary of Breusch and Pagan Lagrangian Multiplier

Test Equation (3)

\begin{tabular}{|l|l|}
\hline & Pre- SFAS 166 \\
\hline Chi-Sq. Statistic & 469.23 \\
\hline Prob>chi2 & 0.000 \\
\hline
\end{tabular}

2- Hausman Test

Table (10) represents the results of Hausman. Therefore, under Pre-FAS 166 period the study rejects the null hypothesis in favor of the FEM.

\section{Table (10)}

The Summary of Hausman Test Equation (3)

\begin{tabular}{|l|l|}
\hline & Pre-SFAS 166 \\
\hline Chi-Sq. Statistic & 11.61 \\
\hline Prob>chi2 & 0.0405 \\
\hline
\end{tabular}


An Analytical study for the Relationship between Accounting for Securitization ...

Prof. Ahmed Zaky \& Ass.Prof. Ragia Shelih

According to the results of table (9) and (10) it can be concluded that the FEM is the appropriate method for testing the third hypothesis in the Pre-SFAS 166 period (2007-2009).

Based on the results shown in Table (8), the findings revealed that the discount rate is negatively and significantly associated with GOS (B1=-.00007566, p<0.001), EBS (B2=$.0000109, \mathrm{P}<0.001)$, and INT-GOS-EBS (B3=-9.113e-13, $\mathrm{p}<0.05$ ). These findings provide evidence that managers use their discretion in fair value rules to pick a lower discount to obtain higher securitization gains. Therefore, $\mathrm{H} 3$ is accepted. In summary, this empirical evidence supports $\mathrm{H} 3$ of the research stating that banks use their discretion to choose lower discount rates to obtain higher securitization gains in Pre- SFAS 166.

\section{Conclusions, Contributions and Future Research}

The findings of this research are important for purposes of analyzing the effectiveness the Financial Accounting Standard SFAS 166 in reducing earnings management practices. The research examined securitization transactions in the two time periods pre and post SFAS 166 to capture changes in the economy and regulations. The overall results indicated evidence of earnings management for the period 2007-2009 when securitization transactions were conducted in accordance with SFAS 140 rules. The results further found that securitization gains were negatively correlated with (1) earnings before securitization, and (2) changes in earnings before securitization. Both were used as proxies for earnings management incentives. Furthermore, the research found a significant and negative association between discount rates and securitization gains. This indicated that banks used their discretion over fair valuation of retained interests to manage securitization gains. However, it was found that there was no indication of 
An Analytical study for the Relationship between Accounting for Securitization ...

Prof. Ahmed Zaky \& Ass.Prof. Ragia Shelih

earnings management existence for the second period 2010-2016 in which securitization transactions were conducted in accordance with SFAS 166 rules. It is argued that companies have become more conservative after the adoption of SFAS 166.

A major contribution of this research is related to examining securitization as a tool for earnings management on a sample of banks. These banks experienced the financial market crises and aftermath. They were exposed to the progress and succeeding preservation of the asset securitization market and to the effects of accounting rules for asset securitizations in SFAS 140 as well as after the application of the current standard SFAS 166. Also, the research provides evidentiary insights on the role of the accounting standard SFAS 166 played in eliminating banks' earnings management practices in securitization settings as compared to the previous Financial Accounting Standard SFAS 140. Therefore, this research posits that securitization is properly regulated, and future financial crisis is not expected to ensue via securitization. Finally, with all the lessons learned from the recent crisis, it can be concluded that most of the criticism pointed to fair value accounting rules SFAS 157 especially in relation to level 3 valuations should be directed toward securitization accounting rule SFAS 140 which allowed for de-consolidation and de-recognition of securitization transactions. This research supports the FASB's (2009) decision to mandate the consolidation of off-balance sheet securitization activities to avoid substantial off-balance sheet activities obscuring the firms' true underlying value. Moreover, although securitization has been considered a key enabler of the financial meltdown, its value as a superior financial tool, along with the necessary control of its application and imperative use of redefined regulations in the SFAS 166 cannot be denied.

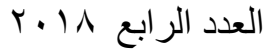

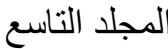


A comparative study across different countries would be a valuable aim for further research to examine companies that are engaged in securitization transactions under both U.S. GAAP and IFRS and determine the possibility of earnings management using securitization transactions across companies operating under different legal regimes. Moreover, this research examines earnings management incentives using two proxies; earnings before securitization and the change in earnings before securitization which is only form of earnings management studied in earnings management literature. It is possible that earnings management incentive is not only related to earning inflation or income smoothing. Thus, future research should also need to examine the use of alternative measures for earnings management incentives and, perhaps, securitization could be used to meet analyst forecasts.

\section{References}

- Altamuro, A. and H. Zhang. 2013. The financial reporting of fair value based on managerial inputs versus market inputs: evidence from mortgage servicing rights. Review of Accounting Studies. Vol. 18, pp: 833-858. Bank for International Settlements (BIS). 2009. Report on Special Purpose Entities. Working Paper. Available at: https://www.bis.org/publ/joint23.pdf

- Barth. M., and W.R. Landsman. 2010. How Did Financial Reporting Contribute to the Financial Crisis? European Accounting Review 19 (3), pp: 399-423.

- Barth, M., G. Ormazabal, and D.J. Taylor. 2012a. Asset Securitization and Credit Risk. The Accounting Review. Vol. 87, (2), pp. 423-448.

- Bertay, A., Gong, D., Wagnere, W. 2017. Securitization and Economic Activity: The credit Composition Channel. Journal of Financial Stability.Vol.28, pp.225-239. 
An Analytical study for the Relationship between Accounting for Securitization ...

Prof. Ahmed Zaky \& Ass.Prof. Ragia Shelih

- Bratten, B., Causholli1, M., and Myers, L. 2017. Fair Value Exposure, Auditor Specialization, and Banks' Discretionary Use of the Loan Loss Provision. Journal of Accounting, Auditing \& Finance. pp:1-31.

- Bryan, S., Lilien, S., and Sarath, B. 2010. Countering Opportunism in Structuring and Valuing Transactions: The Case of Securitizations. Journal of Accounting, Auditing, and Finance. Vol. 25 (2) pp: 289-321.

- Buchanan, B.G., 2016. Securitization: A Financing Vehicle for All Seasons? Journal of Business Ethics. J Bus Ethics Vol.138, pp559-577.

- Briggs, J., and Beams, J. 2012. Asset Securitization in a Changing Environment. The CPA Journal, Vol.82 (9).

- Casu, B., Clare, A., and Thomas, S. 2013. Securitization and Bank Performance. Journal of Money, Credit and Banking. 45(8), pp1617-1658.

- Cerbioni, F., Fabrizi, M., and Parbonetti, A. 2015. Securitizations and the Financial Crisis: Is accounting the Missing Link? Accounting Forum Vol.39, PP: 155-175.

- Chen, W., and Tseng, H. 2012. Evidence of Income Smoothing from Securitized Loans and Loan Loss Provisions: Real Transactions vs. Accruals. The International Journal of Accounting Studies. Vol 54 (1), pp:43-75. Chen, W., and Tseng, H. 2012. Evidence of Income Smoothing from Securitized Loans and Loan Loss Provisions: Real Transactions vs. Accruals. The International Journal of Accounting Studies. Vol 54 (1), pp:43-75.

- Chen, Z., Liu, F., Opong, K., and Chen, M. 2017. Short-Term Safety or Long-Term Failure? Empirical evidence of the impact of securitization on bank risk. Journal of International Money and Finance. Volume 72, Pp: 48-74.

- Cheng, K. 2012. Accounting Discretion and Fair Value Reporting: A Study of US Banks' Fair Value Reporting of Mortgage-Backed-Securities. Journal of Business Finance \& Accounting, Vol. 39(5), pp.531-566.

- Dantas, J., Medeiros, O., Galdi, F., and Costa, F. 2012. Securities-Based Earnings Management in Banks: Validation of a Two-Stage Model. Revista Contabilidade \& Finanças, 24(61), 3754. https://dx.doi.org/10.1590/S1519-70772013000100005.

- Dechow, P., Myers, L., and Shakespeare, C. 2010. Fair Value Accounting and Gains from Asset Securitizations: A Convenient Earnings العدد الرابع r.1^

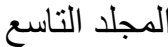


An Analytical study for the Relationship between Accounting for Securitization ...

Prof. Ahmed Zaky \& Ass.Prof. Ragia Shelih

Management Tool with Compensation side-benefits. Journal of Accounting and Economics, Vol. 49, pp. 2-25.

- Farghera, N., and Zhang, J. 2014.Changes in the Measurement of Fair Value: Implications for Accounting Earnings. Accounting Forum. Vol. 38, pp. 184-199.

- Feng, M., Gramlich, J., and Gupta, S. 2009. Special Purpose Vehicles: Empirical Evidence on Determinants and Earnings Management. The Accounting Review: Vol. 84, (6), pp: 1833-1876.

- Financial Accounting Standards Board. 2009. Statement of Financial Accounting Standards No. 166 Accounting for Transfers of Financial Asset. - Norwalk, CT. FASB.

- Haan, L., and Oordt, M. 2017. Timing of Banks Loan Loss Provisioning During the Crisis, Journal of Banking and Finance.

- Huizinga, H. and Laeven, L. 2009. Accounting Discretion of Banks during a Financial Crisis. IMF Working Papers No. 09/207, pp. 1-41 Available at SSRN: http://ssrn.com/abstract=1486525.

- $\quad$ Ibrahim, S. 2010. Servicing Assets and Gain on Securitization under SFAS 156. Working Paper. Available at: http://eprints.kingston.ac.uk/18935/2/Ibrahim-S-18935a.pdf.

- Karaoglu, N. E. 2005. Regulatory Capital and Earnings Management in Banks: The Case of Loan Sales and Securitization. Working Paper, FDIC Center for Financial Research.

- Kolsi, M., and Matoussi, M. 2012. Do managers use Securitisation Gains for Real Manipulation Purposes? International Journal of Managerial and Financial Accounting. Vol.4, (2).

- Krumwiede,T., Scadding, R., and Stevens, C. 2008. Mortgage-Backed Securities and Fair-Value Accounting. The CPA Journal. Vol.78 (5).

- Lejard, C. 2016. Asset Securitization: characteristics of the Securitized Assets and Wealth Effect for Shareholders. Working Paper.

- Pagano, M., and Volpin, P. 2012. Securitization, Transparency, and Liquidity. The Review of Financial Studies 25 (8), PP:2417-2453.

- Paolucci, E. 2016. Fair Value Accounting and the Financial Crisis: A Literature-based Analysis. Journal of Financial Reporting and Accounting, Vol. 14 (1) pp.1 -16. 
An Analytical study for the Relationship between Accounting for Securitization ...

Prof. Ahmed Zaky \& Ass.Prof. Ragia Shelih

- Riddiough, T. 2011. Can Securitization Work? Economic, Structural and Policy Considerations. Journal of Portfolio Management, suppl. Special Real Estate Issue; New York Vol. 37(5), pp: 24-38.

- Sarkkisyan, A., and Casu, B. 2013.Retained interests in Securitizations and Implications for Banks Solvency. European Central Bank. Working Paper Series NO. 1538.

- Senarath, S. 2016. Securitization and the Global Financial Crisis: Can Risk Retention Prevent Another Crisis? Working paper.

- Šodan, S.2015. The impact of Fair Value Accounting on Earnings Quality in Eastern European Countries. Procedia Economics and Finance. Vol. 32, pp. 1769 - 1786.

- $\quad$ Tutino, M., and Pompili, M. 2018. Fair value accounting and management opportunism on earnings management in banking sector: First evidence. Corporate Ownership \& Control. Vol. 15(2).

- Yao, D., Percyb, M., Stewartb, J., and Hub, F. 2018. Determinants of discretionary fair value measurements: the case of Level 3 assets in the banking sector. Accounting and Finance Vol.58, pp:561-597.

- Zhang, 2014 Securitization and Accounting Restatements. Working Paper. Available At: https://papers.ssrn.com/sol3/papers.cfm?abstract_id=2433758. 